\title{
Quality of Work Life and Job Performance: Empirical Evidence from Station Masters Working at Sri Lanka Railways
}

\author{
J. Ramawickrama \\ PhD Candidate, Faculty of Management Studies and Commerce, \\ University of Sri Jayewardenepura \\ (Senior Lecturer, Faculty of Management and Finance, \\ University of Ruhuna, Matara) \\ ramawickrama718@gmail.com
}

H.H.D.N.P. Opatha

Senior Professor

Faculty of Management Studies and Commerce,

University of Sri Jayewardenepura

opatha@sjp.ac.lk

\section{M.D. Pushpakumari}

Senior Lecturer

Faculty of Management Studies and Commerce,

University of Sri Jayewardenepura

pushpakumarimd@sjp.ac.lk

Cite this article: Ramawickrama, j., Opatha, H.H.D.N.P., and Pushpakumari, M.D. (2018), Quality of Work Life and Job Performance: Empirical Evidence from Station Masters Working at Sri Lanka Railways, Sri Lankan Journal of Human Resource Management, Vol. 8, No. 1, pp. 122. 


\begin{abstract}
Quality of work life in an organization is a critical factor for deciding employee related outcomes in modern organizations. The main aim of this study is to investigate the relationship between the dimensions of the quality of work life and job performance dimensions through a survey method using a questionnaire administered to a sample of 280 Station Masters who are employed at Sri Lanka Railways. The construct 'quality of work life' was measured by using eight dimensions based on Walton's model developed in 1975. A three component model including task performance, citizenship performance and counterproductive work dimensions was used for measuring job performance. This study used descriptive statistics, correlation and regression analyses to examine the relationship between the two variables. The result indicates that there is a strong, positive and significant relationship between the two variables and are positive and significant associations among the measurement dimensions of the variables. Further, the quality of work life has a substantial influence on job performance. The paper has of importance as it contributes to the existing body of knowledge originally and the contributions have been specified.
\end{abstract}

Key Words: Job Performance, Quality of Work Life, Railways, Station Masters

\title{
Introduction
}

'Job Performance' (JP) is an important criterion for determining an organizational outcome and its success. Numerous studies available in the literature showed JP to be a central construct in industrial and organizational psychology (Campbell, 1990; Austin and Villanove, 1992; Schmidt and Hunter, 1992; Murphy and Cleveland, 1995). In the literature, JP is simply mentioned as the quantity and quality of the output of each employee who works in an organization. Organizations expect to sustain a better outcome from their workforce throughout their period of employment. Therefore, employee wellbeing is an essential element that needs to be improved in modern organizations. This is because in modern society, employees spend more than one-third of their lives at their workplaces. Schuler and Youngblood (1986) mention that the 'Quality of Work Life' (QWL) involves both job design and work environment. Recently, many researchers have focused on the constructs of QWL and JP, and they have found a positive relationship between the two concepts in different sectors in different countries. Sri Lanka Railways is a government department which functions under the Ministry of Transport. It is a major transport service provider and is the only rail transport organization in the country. The rail transportation system was introduced to 'Sri Lanka' (formerly Ceylon) in 1864 during the British colonial era. With the mission of the "Provision of safe, reliable and punctual rail transport service for both passengers and freight traffic, economically and efficiently", this organization provides a huge service to the country. According to the Performance Report of Sri Lanka Railways (2016), the number of current employees is around 14,865. Hence, the employees who work in the organization have become the backbone of this organization. Station Master is one of the employment categories among the employees of the railways. The Station Master is an officer appointed by the General Manager Railways to be in over-all charge of a station. Since they have a very heavy work load in this special job category, only males are employed 
as Station Masters in the Sri Lanka Railways. The writer and novelist, Ellis (1994, p.3), who was as a regular user of railway transport in Sri Lanka, has penned his feelings as follows. "I am grateful to the railway men, particularly the Guards, Drivers and Station Masters who are proud of the Railways and have always been helpful with information and advice." The above statement provides evidence for the fact that the three parties mentioned can be considered as one main group related to operating and service providing activities of the railways. Hence, this study is important in that it provides empirical evidence regarding the relationship between the QWL and JP in the railway sector.

Problem Context: Many researchers have defined JP differently during different decades, and they have used various dimensions for measuring JP among workers engaged in different professions around the world. Hence, Ramawickrama, Opatha and Pushpakumari (2017b) reviewed recent empirical findings and found the necessity of employing different dimensions of JP for workers involved in a multiplicity of careers in many different types of organizations, globally. As a result, researchers are faced with the difficulty of applying clearcut measurement dimensions for measuring JP. Walton (1975) highlighted QWL as consisting of humanistic values and social responsibilities in an organization. Therefore, QWL is an approach or a method used for improving work in an organization (Ford, 1973). However, the concept of QWL is an abstract construct, having less measurable and observable properties than a concrete one. Therefore, researchers are faced with difficulties in defining and measuring this abstract concept due to its subjective nature. In addition, Beh (2011) points out that there is no one size of QWL that fits all organizations in any country. Every organization needs to develop its own unique QWL to represent its employee, customer and organizational needs. Consequently, the researchers needed to find suitable measurement dimensions of QWL for the railway sector in Sri Lanka. However, there are only a limited number of empirical results related to Sri Lanka Railways. The study of Kesavan, Chandrakumar, Kulatunga, Gowrynathan, Rajapaksha, Senewiratne, and Laguleshwaran (2015) has revealed many issues of productivity related to the railways, together with some suggestions for improvement. As they point out, though Sri Lanka Railways has a 150 year old history, the current level of service and work facilities are not at a satisfactory level. Due to the lack of adequate empirical evidence showing the relationship between QWL and JP, it is necessary to find empirical evidence from Station Masters who work in the Sri Lanka Railways.

\section{Objectives}

This study focuses on finding adequate empirical evidence to reveal the nature of the relationship between QWL and JP of Station Masters who work in the Sri Lanka Railways. Specifically, the following research objectives were attempted to achieve:

1. To investigate whether there is a positive relationship between the QWL and JP of Station Masters in Sri Lanka Railways.

2. To examine the association among the eight dimensions of QWL and the three dimensional model of JP relevant to Station Masters in Sri Lanka Railways.

3. To predict the impact of the QWL on JP of Station Masters in Sri Lanka Railways. 


\section{Theory and Literature Review}

Definitions of Job Performance: JP is a very popular construct among researchers for measuring results of individual employees in an organization. Different researchers have defined JP differently through the decades. A few of them are, JP is a function of individual ability, skills and effort in a given situation (Porter and Lowler, 1974), the record of outcomes produced by a specified job function or activity during a specified time period (Bernardin and Beatty, 1984), behaviors or actions relevant to the goals of the organization (Campbell, 1990), the record of outcomes produced by a specified job function or activity during a specified time period (Bernardin and Russel, 1993), scalable actions, behavior and outcomes that employees engage in or bring about that are linked with and contribute to organizational goals (Viswesvaran and Ones, 2000), the contribution that individuals make to the organization that employs them (Steward and Brown, 2009), and an employee's JP is the extent to which duties and responsibilities of the job have been carried out and two major criteria for measuring JP are the quantity of work and quality of work (Opatha, 2015).

Dimensions of Job Performance: Many researchers have discussed the dynamic nature of JP and have used numerous dimensions for measuring it till now. The following are some ways that previous researchers attempted to measure JP: Objective evaluation and subjective evaluation form of JP (Burtt, 1926; Viteles, 1932 as cited in Viswesvaran, 2001), hard criteria and soft criteria of JP (Smith, 1976), direct measures and indirect measures of JP (Schmidt 1976 as cited Viswesvaran, 2001), and judgmental vs. non-judgmental measures of JP have been reviewed in the literature (Landy and Farr, 1983). Thirteen types of pro-social organizational behaviors were discussed by Brief and Motowidlo in 1986. Murphy (1989) elaborated four dimensions, including task oriented behavior, interpersonally oriented behavior, down-time behavior and destructive or hazardous behavior. Campbell, McHenry, and Wise (1990) proposed eight performance components for measuring JP. In-role work performance and extra-role performance were presented by Borman and Brush in 1993. In the same year, with an awareness of the multi-dimensional nature of JP, both concepts of task performance and contextual performance were classified JP by Borman and Motowidlo (1993). On the other hand, perspectives of JP such as "generic work behavior" and "adaptive performance behavior" were discussed by Hunt (1996) and Pulakos, Arad, Donovan, and Plamondon (2000), respectively. Recently Koopmans, Bernaards, Hildebrandt, Schaufeli, De Vet, and Beek (2011) conducted a systematic review process and proposed four theoretical dimensions including task performance, contextual performance, adaptive performance, and counterproductive work behavior as taxonomies of JP. However, many authors have conducted studies related to JP, and have defined the concept of JP variously, and have used different dimensions for measuring it. Based on the above authors and their measurement dimensions, Ramawickrama, Opatha and Pushpakumari (2017b) have found widely used JP dimensions, namely, Task performance, Contextual performance, Adaptive and Counterproductive work behavior and Citizenship behavior.

Ramawickrama, et al. (2017b) proposed a working definition for their study i.e. "Job Performance is the extent to which the employee has shown his or her traits, engaged in behaviors and produced results which are appropriate to task performance, and has 
engaged in citizenship performance and counterproductive performance during a particular period of time". Accordingly, three measurement dimensions were identified: 1. Task performance (TP), 2. Citizenship performance (CP), and 3. Counterproductive performance (CPP).

Definitions of Quality of Work Life: QWL has been defined in many ways by various authors from different geographical settings. This shows that it is an abstract concept, and is also subjective in nature. As per the definition given by the International Labor Relations Conference, QWL is about creating the conditions for a humane working life. Boisvert (1977) presented the beneficial consequences of QWL by including three aspects, namely, individual employees, the organization and society. The American Society of Training and Development considered that QWL was needed to achieve the twin goals of effectiveness of the organization and employee improvement. Therefore, some authors considered the organizational perspective of QWL (Carlson, 1983; Cummings and Worley, 1997), while others considered the employee perspective of QWL (Nadler and Lawler, 1983; Kiernan and Knutson, 1990). Opatha (2009) theorized that the concept of QWL could be considered as one of the strategic goals of Human Resource Management. Walton (1975) introduced this concept as an eight dimensional model measuring humanistic values and social responsibilities in an organization. Martel and Dupuis (2006) noted that no universally accepted definition of the QWL has been formulated yet, except the fact that it has to do with the well-being of employees in an organization.

Dimensions of the Quality of Work Life: Different researchers have used different dimensions for measuring this construct. Krueger, Edward, Lewis and Tjam (2002) mentioned that QWL is an "umbrella term" which includes many concepts. As it is as an abstract construct having less measurable and observable properties than a concrete concept, researchers face difficulties in defining and measuring it due to its subjective nature. For example, recent studies show that only a minimum number of measurement dimensions (03 dimensions) have been applied by Rose, Beh, Uli and Idris (2006), Gnanayudam and Dharmasiri (2007) and Al Muftah and Lafi (2011). The maximum number of measurement dimensions (14 dimensions) has been used by Saraji and Dargahi (2006) and Satyaraju and Balaram, as cited in 2015 Bora, Saumendra and Murthy (2015). Between 03 to 14 dimensions have been used by researchers from different contexts namely as those by Walton (1975), Saklani (1979), Levine, Taylor and Davis (1984), Mirvis and Lawler (1984), Baba and Jamal (1991), Lau and May (1998), Wyatt and Wah (2001), Rathinam and Ismail (2007), Hosseini (2010), Tabassum (2011), Stephen and Dhanapal (2012), Mazloumi, Kazemi, NaslSaraji and Barideh (2015), Swamy, Nanjundeswaraswamy and Rashmi (2015) and Almarshad (2015). However, in 1975, Walton defined the quality of work life as consisting of humanistic values and social responsibilities in an organization, and included eight dimensions in his model, namely, adequate and fair compensation, safe and healthy working conditions, immediate opportunity to use and develop human capacities, opportunity for continued growth and security, social integration in the work organization, constitutionalism in the work organization, work and total life space and the social relevance of work life. Further, Beh (2011) described that there is no one size to the QWL that fits all organizations in any 
country. Every organization needs to develop its own construct to represent its unique employee, customer and organizational needs (Walton, 1975).

Hence, the following definition is used for QWL as the working definition of this study "Quality of work life is the degree of availability of features for ensuring a humane working life for each employee of the organization" (Ramawickrama et al., 2017a). The construct of QWL was categorized into eight dimensions, i.e. Basic salary and fair compensation (QWL 1), Work conditions (QWL 2), Safe and healthy work environment (QWL 3), Development of human capacity (QWL 4), Social integration in work organization (QWL 5), Constitutionalism in work organization (QWL 6), Balance between work and non-work life (QWL 7), and Social relevance of work life (QWL 8).

Relationship between QWL and JP: The literature findings reveal that the construct of QWL is one of the more popular topics related to the HRM discipline. A considerable number of researchers have engaged in work related to QWL and JP representing different sectors worldwide. Lau and May (1998) indicated that QWL is a significant factor in determining JP. Expanding on this idea, Havlovic (1991) explained that QWL enhances the performance of employees and found that QWL significantly reduces absenteeism, minor accidents, grievances and turnover of employees in an organization. Positive QWL is the favorable conditions at and environment of the workplace that address the welfare and well-being of employees. In 2008, Korunka et al. as cited in Nayak (2015), mentioned that "there is a plethora of literature stating that organizations providing desirable QWL for its employees can achieve better human resource productivity and performance". Rose et al. (2006), under the topic 'Linking Quality of Work Life and Job Performance: Implications for Organizations', found that there is a significantly strong positive relationship between QWL and JP. Sabarirajan, Geethanjali and Lavanya (2011) conducted a research study in relation to private and public banks in Dindigul and concluded the relationship between QWL and JP.

Accordingly, the research revealed that the performance of an organization can be improved only when human resources are satisfied with a higher QWL. Talebi, Pakdelbonab, Zemestani and Aghdami (2012) found that a significant relationship exists among the variables of salary and benefits, job security, health and secure work environment, autonomy at work, providing the basis for skills education, on determining job development direction with employee effectiveness. Varghese and Jayan (2013) mentioned that QWL and its relationships with employee health and performance have become an explicit objective of many human resource policies in modern organizations. Nair (2013) conducted a study with school teachers in the Thrissur district of Kerala under the topic 'Effect of QWL on Organizational Citizenship Behavior'. The results showed that there is a significant difference in the effect of QWL on organizational citizenship behavior between men and women. Women showed a higher level of job dedication than men. Shekari, Monshizadehand Ansari, (2014) found a relationship between QWL and employees' performance in the Water and Waste-water office in Khorasan Razavi. They concluded that there is a positive relationship among the variables and ranked the elements based on the Friedman model of the factors of QWL, including chances for growth and security, safe work conditions, development of 
capacities, social relevance of work in life, fair and appropriate compensation, constitutionalism, social integration in the organization and work and total life space. Rai (2015), in a study of Indian IT professionals under the topic 'Does QWL have an effect on job performance?' found that the concept of QWL has a strong impact on JP. The result of the above study shows that past studies indicate that there is a strong, positive relationship between QWL and JP.

Empirical Findings in the Railway Sector: In 2010 Ranjan and Prasad made a study under the topic 'Working-Conditions, Stress and their Outcomes: A Review Study among Loco-Pilots (Railway Drivers) in India' and found that drivers face an extremely stressful and fatiguing work environment and a high probability of accidents. As solutions to these problems, they suggested ergonomics of the driver's cabin, leisure time activities and psychological training. Hosmani and Shambhushankar (2014) studied the impact of the QWL on JP amongst employees of South Central Railways. Several aspects of the QWL have been analysed in this study including working conditions, safety measures, welfare practices, and career development opportunities. This study reveals that there is a high level of satisfaction among these employees regarding their QWL as it enhances organizational performance as well. Mazloumi et al. (2014) have performed an assessment of the QWL among train drivers in Iran railways, and have concluded that improving working conditions and home-work interface were appropriate measures for improving the QWL of train drivers. Verma (2015) suggested that there is a significant positive relationship between the QWL and job satisfaction among diesel locomotive employees in Varanasi.

Representing the Sri Lankan context, Halpita and Thelijjagoda (2011) did an exploratory study on how technology makes changes in railway transportation in Sri Lanka. They found that "most of the work related to the Sri Lanka Railway service is done manually, and also highlight that the early established manual system is inappropriate for the current situation and it creates lots of problems for workers and passengers".

Being a state-owned enterprise, Sri Lanka Railways earns 7.5 billion Rupees as its net income while managing around 14,400 employees (Performance Report, 2017). The "Station Master" is the officer appointed by the General Manager to be in overall charge of the station. Since a heavy workload is associated with this special job category, only males are employed as station masters in Sri Lanka. All railway servants employed at the station or within its limits are subject to the Station Master's authority and directions in the working of the station. Hence, the scope of the Station Master's responsibility is vast. He must control and maintain the day to day activities of a particular station and needs to be responsible for the admission of trains. He is also the person who manages relations with external customers who may be passengers or cargo owners.

Mani, Sritharan and Gayatri (2014) studied the effect of occupational stress on the QWL among railway Station Masters of the Trichy division in Tamil Nadu. They concede that many researchers have searched for occupational stress of jobs such as pilots, nurses, accountants, teachers, university academics, managers and IT professionals but few 
researchers have touched on railways (engine pilots), and there are no studies in relation to the job category of Station Masters. Further, they declared that the Station Master is in charge of the reception and dispatch of trains, ensuring safety, running of trains, safety of cargoes, as well the lives of railway passengers. As a result of this highly stressful workload, poor quality of performance, lower job satisfaction, high turnover and increased work absence or lack of concentration on the job may occur. So, it is agreed that it is vital to enhance the QWL of employees in order to reduce the negative effects of a lower level of QWL. The general understanding is that any employed person spends nearly one third of his or her life in the work place. This general understanding does not apply to Station Masters because they have to work and live with their profession. Kesavan et al. (2015) have conducted their research on the topic ' 150 Years of Sri Lankan Railways: Evaluation of the Services from Employee and Customer Perspectives' in order to recognize the customer's perspective on the current level of quality and to identify his/her grievances, as well as to investigate the employee perspective on the current administration and functionality of Sri Lankan Railways. They have made important suggestions through their findings and have mentioned that "when compared with many other developing countries in the region, though the Ceylon railway has 150-year long history, the current level of service and working facilities are not at a satisfactory level".

\section{Conceptual Model}

A conceptual model was developed to exhibit the relationship between QWL and JP and it is given in Figure 1.

Figure 1: Conceptual Model of the Study

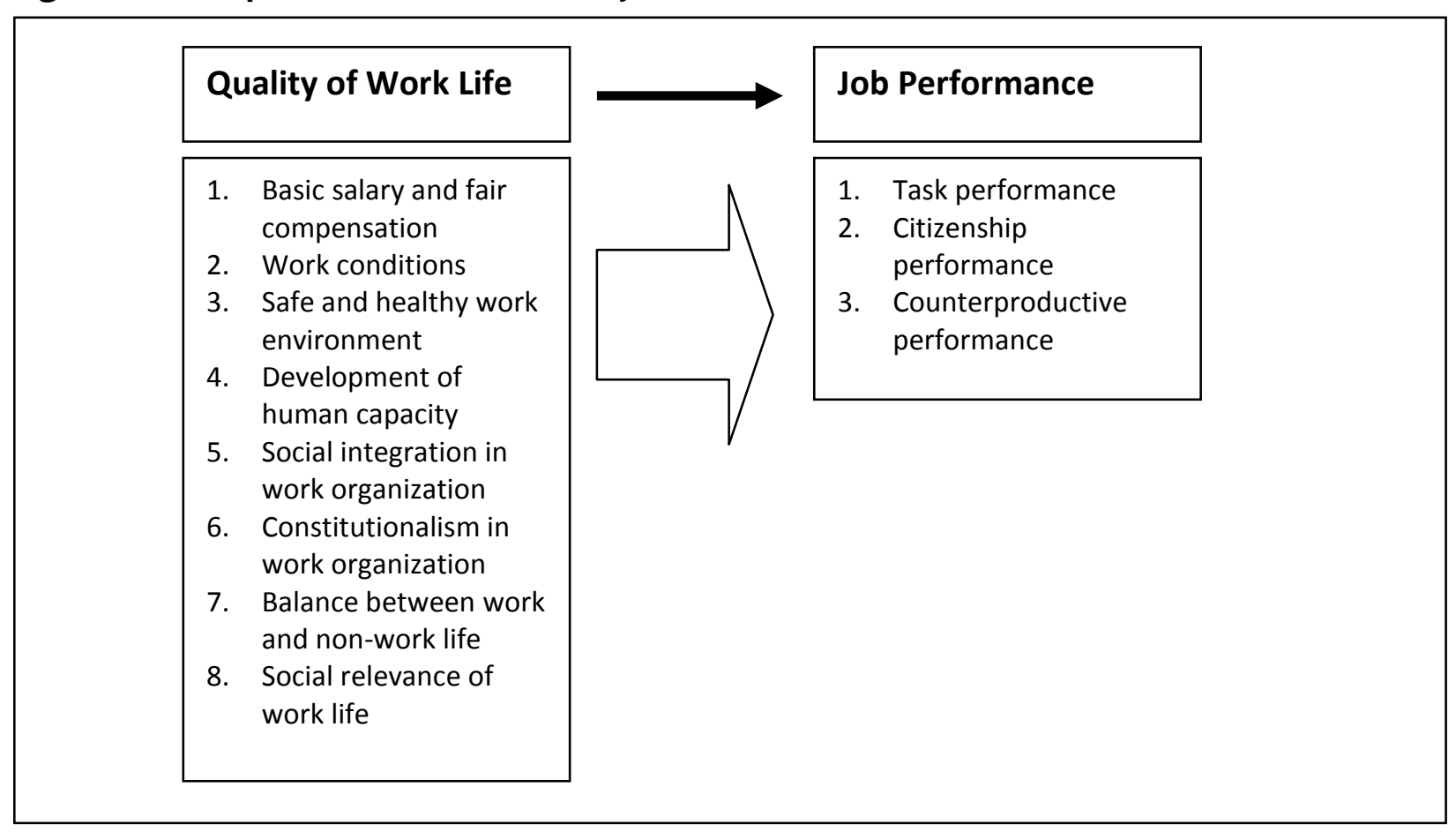


Based on theoretical and empirical evidence, a conceptual model was developed and from which three hypotheses were derived.

Hypothesis 1: There exists a positive and significant relationship between QWL and JP of Station Masters who work in Sri Lanka Railways.

Hypothesis 2: There is an association between the eight dimensions of QWL and the three dimensional model of JP.

Hypothesis 3: There is a significant impact of QWL on JP of Station Masters who work in Sri Lanka Railways.

\section{Methods}

Designing the Research: A quantitative study was conducted to achieve the expected objectives, and the main focus of the study was explaining the eight dimensions of QWL that contribute to JP of railway workers in Sri Lanka. 280 Station Masters were selected by a stratified sampling technique based on Krejcie and Morgan (1970). Survey questionnaires were administered among the respondents who work in Sri Lanka Railways. The majority of people of the sample were Sinhala and the minority included Muslims and Tamils. Therefore, questionnaires were printed in both English and Sinhala languages.

Instruments and Measures: The two variables in the conceptual model, i.e. QWL and JP, were measured using the multi-item interval scales developed by the authors, and validated prior to final data collection. The variables were carefully conceptualized and operationalized based on previous literature/ theories, to develop the individual measurement instruments. The dimensions and the elements of variables presented in Exhibit 1 and Exhibit 2 were used to develop the multi-item individual measurement instruments. These elements were used to develop question items in order to capture primary data from participants. The responses were captured on a 5-point Likert scale, with scores ranging from 1 to 5 - strongly disagree (1), disagree (2), neither agree nor disagree (3), agree (4) and strongly agree (5), respectively. Eighty-nine (89) question items were itemized including 12 questions for demographic factors of respondents, 31 questions for QWL, 46 for $J P$ and an open question for respondents' feelings, suggestions and comments. The final questionnaire was pre-tested and validated prior to being used in the primary data collection. Accordingly, Exhibit 1 shows more details for dimensions and elements of JP used for the study. Exhibit 2 presents dimensions and elements of QWL used for the study. 


\section{Exhibit 1: Dimensions and Elements of the Variable of JP for Development of the Measurement Instrument}

\begin{tabular}{|c|c|c|}
\hline Dimension & Elements & Reference \\
\hline TP & $\begin{array}{l}\text { Task performance-result based: } \\
\text { Delays of train arrival and delays of train departure due to lack of } \\
\text { preparation, proper coordination among the relevant parties, } \\
\text { passenger complaints, cargo handling, accidents, complaints } \\
\text { received from subordinates, solving passenger inquiries or } \\
\text { solving problems, and employees' praises. } \\
\text { Task performance-behavioral based: } \\
\text { Supervising subordinates' duties, oral communication with } \\
\text { people, observation of passenger, caring to handle all the duties } \\
\text { correctly, caring to wear the uniform and other ornaments, } \\
\text { relationships with the relevant external parties, and cleanliness } \\
\text { of the station. } \\
\text { Task performance- trait based: } \\
\text { Language fluency and knowledge, leadership ability, } \\
\text { coordination ability, ability to understand operating tasks, ability } \\
\text { to perform the tasks according to the context, monitoring and } \\
\text { controlling resources/ cost consciousness, and respect for others } \\
\text { and friendships with others. }\end{array}$ & $\begin{array}{l}\text { Murphy, 1989; } \\
\text { Borman and } \\
\text { Motowidlo, 1993; } \\
\text { Viswesvaran and } \\
\text { Ones 2000; } \\
\text { Rotundo and } \\
\text { Sackett, 2002; } \\
\text { Stokes, 2008; } \\
\text { Stewart and } \\
\text { Brown, 2009; } \\
\text { Koopman, et al. } \\
\text { 2011; Safety Rules } \\
\text { of Railways (SRR) }\end{array}$ \\
\hline CP & $\begin{array}{l}\text { Organizational level citizenship behavior: } \\
\text { Sending a notice in advance when unable to come to work, } \\
\text { protect the organization's properties, contributing to the } \\
\text { implementation of special activities, and handling extra } \\
\text { responsibilities. } \\
\text { Interpersonal citizenship behavior: } \\
\text { Giving support to help people who have been absent, giving } \\
\text { support to solve coworkers' personal problems, spending time } \\
\text { to solve subordinates' personal problems, and participating in } \\
\text { group activities. }\end{array}$ & $\begin{array}{l}\text { Organ, 1988; } \\
\text { Viswesvaran and } \\
\text { Ones, 2000; } \\
\text { Rotundo and } \\
\text { Sackett, 2000; } \\
\text { Stewart and } \\
\text { Brown, 2009; } \\
\text { Scott and Judge, } \\
\text { 2009. }\end{array}$ \\
\hline CPP & $\begin{array}{l}\text { Production related deviant behavior: } \\
\text { Delaying or reducing speed of the service, and losses or wasting } \\
\text { resources due to carelessness of employee. } \\
\text { Property related deviant actions: } \\
\text { Money leakages, property misusage, damages caused to assets, } \\
\text { occurrence of harmful actions, and misuse of office time. } \\
\text { Political deviant actions: } \\
\text { Harmful actions to employee career, favoritism due to internal } \\
\text { politics, participation in union strikes, and participation in } \\
\text { sabotage due to internal politics. } \\
\text { Personal aggression: } \\
\text { Inappropriate physical actions, inappropriate verbal } \\
\text { harassments. }\end{array}$ & $\begin{array}{l}\text { Robinson and } \\
\text { Bennett,1995; } \\
\text { Viswesvaran and } \\
\text { Ones, 2000; } \\
\text { Rotundo and } \\
\text { Sackett, 2002; } \\
\text { Dunlop and Lee } \\
\text { 2004; Koopmans, } \\
\text { et al., 2011 }\end{array}$ \\
\hline
\end{tabular}


Exhibit 2: Dimensions and Elements of the Variable of QWL for Development of the Measurement Instrument

\begin{tabular}{|c|c|c|}
\hline Dimension & Elements & References \\
\hline $\begin{array}{l}\text { QWL } 1 \\
\text { Basic salary and } \\
\text { fair } \\
\text { compensation }\end{array}$ & $\begin{array}{l}\text { Level of satisfaction with basic salary, } \\
\text { competitive salary level comparing with } \\
\text { others, and extra non-financial benefits }\end{array}$ & $\begin{array}{l}\text { Walton,1975; Saklani, 1979: } \\
\text { Hosseini, 2010; Stephen and } \\
\text { Dhanapala, 2012; Tabassum, } \\
2012 \text { and Mirvis and Lawler, } \\
1984\end{array}$ \\
\hline $\begin{array}{l}\text { QWL } 2 \\
\text { Work conditions }\end{array}$ & $\begin{array}{l}\text { Assigned work shifts during a particular } \\
\text { time period, work load for a particular } \\
\text { week or month, level of technology } \\
\text { usage in work, and adequate facilities } \\
\text { within the work surrounding }\end{array}$ & $\begin{array}{l}\text { Saklani, 1979; Levin, 2002; } \\
\text { Saraji and Dargahi, 2006; } \\
\text { Rathinam and Ismail, 2007; } \\
\text { Mazloumi et al., } 2014 \text { and } \\
\text { Almarshad, } 2015\end{array}$ \\
\hline $\begin{array}{l}\text { QWL } 3 \\
\text { Safe and healthy } \\
\text { work } \\
\text { environment }\end{array}$ & $\begin{array}{l}\text { Safety equipment, health problems or } \\
\text { diseases, conflicts among internal and } \\
\text { external parties, and tiredness }\end{array}$ & $\begin{array}{l}\text { Walton, 1975; Mirvis and } \\
\text { Lawler, 1984; Saraji and } \\
\text { Dargahi, 2006; Hosseini, 2010; } \\
\text { Stephen and Dhanapala, 2012 }\end{array}$ \\
\hline $\begin{array}{l}\text { QWL } 4 \\
\text { Development of } \\
\text { human capacity }\end{array}$ & $\begin{array}{l}\text { Satisfaction with received autonomy to } \\
\text { make decisions, ability to perform } \\
\text { several tasks at once, training related } \\
\text { to job, and career growth opportunities }\end{array}$ & $\begin{array}{l}\text { Walton, 1975; Saklani, 1979; } \\
\text { Mirvis and Lawler, 1984; Lau } \\
\text { and Bruce, 1998; Hosseini, } \\
\text { 2010; Stephen and Dhanapala, } \\
2012 \text { and Tabassum, } 2012\end{array}$ \\
\hline $\begin{array}{l}\text { QWL } 5 \\
\text { Social integration } \\
\text { in work } \\
\text { organization }\end{array}$ & $\begin{array}{l}\text { Satisfaction with the communication } \\
\text { among members, human relations and } \\
\text { social aspect of work life, and team } \\
\text { commitment among the employees }\end{array}$ & $\begin{array}{l}\text { Walton, 1975; Saklani, } 1979 \\
\text { and Tabassum, } 2012\end{array}$ \\
\hline $\begin{array}{l}\text { QWL } 6 \\
\text { Constitutionalism } \\
\text { in work } \\
\text { organization }\end{array}$ & $\begin{array}{l}\text { Workers' rights, freedom of expression } \\
\text { of ideas, respect to individuals, } \\
\text { grievances handling, and existing } \\
\text { transfer system and punishment } \\
\text { system of the organization. }\end{array}$ & $\begin{array}{l}\text { Walton, 1975; Saklani, 1979; } \\
\text { Mirvis and Lawler, 1984; } \\
\text { Opatha, 1994; Stephen and } \\
\text { Dhanapala, } 2012 \text { and } \\
\text { Tabassum, } 2012\end{array}$ \\
\hline $\begin{array}{l}\text { QWL } 7 \\
\text { Balance } \\
\text { between work } \\
\text { and non-work } \\
\text { life }\end{array}$ & $\begin{array}{l}\text { Family response culture, sufficient } \\
\text { leisure time, and satisfaction towards } \\
\text { work life and family life }\end{array}$ & $\begin{array}{l}\text { Walton, 1975; Saklani, 1979; } \\
\text { Rathinam and Ismail, 2007; } \\
\text { Stephen and Dhanapala, } 2012 \\
\text { and Tabassum, } 2012\end{array}$ \\
\hline $\begin{array}{l}\text { QWL } 8 \\
\text { Social relevance } \\
\text { of work life }\end{array}$ & $\begin{array}{l}\text { Being proud of the work, Institutional } \\
\text { image, and Community integration }\end{array}$ & $\begin{array}{l}\text { Walton, } 1975 \text { and Tabassum, } \\
2012\end{array}$ \\
\hline
\end{tabular}


Instrument Reliability and Validity: Reliability is concerned with consistency over times of administration of the instrument to the same respondents and consistency across the question items (Sekaran, 1992; Opatha, 2003). As mentioned by Sekaran and Bougie (2013), several types of reliability tests were used for the goodness of measures. Internal consistency was considered and Cronbach's alpha for the overall value of QWL was 0.941. The Cronbach's alpha value of the overall JP was measured. The task performance (TP) indicated an alpha value of 0.819 , citizenship performance (CP) indicated 0.891 and counterproductive performance (CPP) was 0.740 . Moreover, a reliability coefficient value of above 0.7 is statistically acceptable for a study (Nunnally, 1978). The test-retest coefficient is 0.931, which is significant at the $99 \%$ confidence level. The result suggests that the instruments possess a high degree of test-retest reliability. The values of KMO were above the cut-off point of 0.5 which indicates a good range of sample adequacy, and the values of constructs were significant as per Bartlett's test of sphericity. Conceptualization and operationalization ensured the content validity of the variables.

Data Analysis Techniques: The Statistical Package for the Social Sciences (SPSS) is a widely used computer program that allows quantitative data to be managed and analyzed (Bryman and Bell, 2011; Sekeran and Bougie, 2013). Four hundred questionnaires were distributed for the survey, of which 287 questionnaires were returned, reporting a 71.75\% response rate. Data were coded, cleaned and treated for missing values and outliers for ensuring the accuracy of the conclusions drawn from the study. Frequencies and descriptive analyses were conducted to present the main characteristics of the sample and respondents' perceptions related to each and every dimension. The Pearson Product-Moment Correlation technique was used to test the first two hypotheses $\left(\mathrm{H}_{1}\right.$ and $\left.\mathrm{H}_{2}\right)$ and the third hypothesis was tested by regression analysis.

\section{Results}

Demographic Information of the Sample: The uniqueness of this sample was its homogeneity. This is because all the Station Masters are males who have represented all stations in Sri Lanka. 200 respondents out of the 280 had experienced more than 5 years of service and they had worked at more than 4 stations during their service period. While the majority of the respondents (236) were included in the 25-55 age category, 24 of the respondents were over 56 years. Further, this sample represented all three major ethnic groups, comprising of Sinhalese, Tamils and Muslims. The majority of them were married with children. Only 103 of the respondents lived in the railway quarters and of them, 63 lived with their families. The other 40 Station Masters lived alone in the railway quarters.

Respondents' Perceptions on the QWL: The calculation of the descriptive values for each and every measurement dimension of QWL is shown in Table 1. The mean score of the perception level regarding basic salary and benefits (QWL1) is 3.35. It is an above average value on the five point scale. Therefore, it is at a favorable level in the scale. The SD value for QWL1 is 0.68 which is less than 1, indicating only minor dispersion. This indicates that in general, the degree of QWL as perceived by Station Masters is fairly satisfactory. The mean of working condition at work (QWL2) felt by Station Masters is 3.029, which is above 
average on the five point scale. The SD is less than 1 indicating a low dispersion level $(S D=0.59)$. This indicates that in general, Station Masters are fairly satisfied at work.

Table 1: Overall Perception on QWL

\begin{tabular}{lrrrr}
\hline \multicolumn{1}{c}{ Dimensions of QWL } & N & Mean & SD & $\begin{array}{c}\text { Mean } \\
\text { Importance }\end{array}$ \\
\hline Basic salary and extra benefits (QWL1) & 280 & 3.355 & .68 & 03 \\
Working conditions (QWL2) & 280 & 3.029 & .59 & 06 \\
Safe and healthy work environment (QWL3) & 280 & 2.767 & .54 & 08 \\
Opportunity for development of human capacity & 280 & 2.892 & .57 & 07 \\
(QWL4) & & & & \\
Social integration in work organization (QWL5) & 280 & 3.691 & .56 & 02 \\
Constitutionalism (QWL6) & 280 & 3.049 & .58 & 05 \\
Balance between work and non-work life (QWL7) & 280 & 3.070 & .76 & 04 \\
Social relevance and importance of QWL (QWL8) & 280 & 4.046 & .62 & 01 \\
\hline Overall average of QWL & $\mathbf{2 8 0}$ & 3.235 & .399 & \\
\hline
\end{tabular}

The next two dimensions of safe and healthy work environment (QWL3) and opportunity for development of human capacity (QWL4) are below the average levels on the five point scale. The values for both SD are 0.54 and 0.57 , respectively. This indicates only slight dispersion. Consequently, the nature of the level of perception is low. The mean of attitudes to social integration in work organization (QWL5) is 3.691, which is above average on the five point scale. The SD is 0.56 , and this indicates a slight degree of dispersion. In general, the results indicate that Station Masters experience a satisfactory level of social relations at the workplace. Constitutionalism (QWL6) surrounding the work and work environment shows a mean value of 3.049, and that is also above average on the five point scale and the 0.58 SD value shows only a little variance, as it is less than 1. It can be seen from these results that the majority of Station Masters have neither negative nor positive attitudes towards the existing constitutions of their work environment. Perception related to work and nonwork life (QWL7) faced by Station Masters is 3.070, and it also is above average on the five point scale. The SD is 0.76 , which is close to 1 , and it indicates a rather small dispersion. Therefore, respondents are satisfied to some extent. Social relevance and importance of QWL (QWL8) indicates a mean value of 4.046. It comes under the 'satisfactory' category of the five point scale. However, its SD is 0.62 which is somewhat higher than the other SD values in the table, but does not exceed 1. Hence, a majority of Station Masters think that they render an appreciable service to the society.

According to Table 1, majority of the mean values are above the average on the five point scale, and all the SD values are less than 1. It seems that Station Masters in the railway sector have an appropriate QWL. Those dimensions can be ordered based on the mean importance, as given below. The highest importance dimension is the social relevance and importance of QWL, the next two dimensions (second and third) are social integration in the work organization and basic salary and extra benefits. The fourth is the balance between 
work life and non-work life, and the fifth place is occupied by constitutionalism. The dimensions with the lowest importance, namely, the sixth, seventh and eighth dimensions, respectively, are working conditions, the opportunity for development of human capacity and safe and healthy work environment.

Table 2 includes three main dimensions of JP namely; task performance, citizenship performance and counterproductive performance.

Table 2: Descriptive Statistics of JP

\begin{tabular}{lcrrrr}
\hline & N & Minimum & Maximum & Mean & $\begin{array}{c}\text { Std. } \\
\text { Deviation }\end{array}$ \\
\hline Task performance (TP) & 280 & 1.92 & 4.84 & 3.917 & .47 \\
Citizenship performance (CP) & 280 & 1.50 & 5.00 & 3.730 & .63 \\
Counter - productive performance & 280 & 3.00 & 5.00 & 4.632 & .33 \\
(CPP) & & & & & \\
\hline
\end{tabular}

TP comprises of result based, behavioral based and trait based performance. Taken as a whole, TP of this study has a 3.917 mean value. It is above average on the five point scale. The SD value of TP is 0.47 , which is very low. Consequently, the results indicate that Station Masters are performing tasks to a satisfactory or more than satisfactory level. The total CP consists of two types: organizational citizenship performance and interpersonal citizenship performance. The mean value of total $\mathrm{CP}$ is 3.730 and it is above average on the five point scale. SD is 0.63 , which shows a low dispersion behavior. Consequently, the results reveal positive attitudes related to $C P$. The final component CPP which has the highest mean value (4.63). Moreover, it indicates the lowest SD value of 0.33 when compared to the other constructs. Hence it can be concluded that Station Masters have positive perception towards their performance.

Testing of Hypotheses: Pearson Product-Movement Correlation technique was used to test hypotheses one and two, and the results are given in Table 3 and 4.

Table 3: Correlation between QWL and JP

\begin{tabular}{llr}
\hline & & Tot JP \\
\hline \multirow{3}{*}{ Total QWL } & Pearson Correlation & $.704^{* *}$ \\
& Sig. (1-tailed) & .000 \\
& $\mathrm{~N}$ & 280 \\
\hline
\end{tabular}

Hypothesis one stated that there exists a positive and significant correlation between QWL and JP of Station Masters who work in Sri Lanka Railways. The statistical results in Table 3 indicate a correlation coefficient value of $0.704{ }^{* *}$ significant at the $99 \%$ confidence level. This result substantiates that there exists a strong positive and significant relationship between the variables. Hence, the null hypothesis is rejected and the alternative hypothesis is accepted. 
Table 4 shows the nature of the association between the eight dimensions of QWL and the three dimensional model of JP. Hypothesis 2 states that there is an association between the eight dimensions of QWL and the three dimensional model of JP.

Table 4: Association between QWL Dimensions and JP Dimensions

\begin{tabular}{llll}
\hline \multicolumn{1}{c}{ Dimensions } & TP & CP & CPP \\
\hline QWL-1 Basic salary and fair compensation & .052 & -.004 & .041 \\
QWL-2 Work conditions & .058 & -.006 & .186 \\
QWL-3 Safe and healthy work environment & $.043^{* *}$ & -.031 & $.105^{* *}$ \\
QWL-4 Development of human capacity & $.346^{* *}$ & $.278^{* *}$ & $.246^{* *}$ \\
QWL-5 Social integration in work organization & $.555^{* *}$ & $.518^{* *}$ & $.192^{* *}$ \\
QWL-6 Constitutionalism in work organization & $.579^{* *}$ & $.513^{* *}$ & $.280^{* *}$ \\
QWL-7 Balance between work and non-work life & $.537^{* *}$ & $.510^{* *}$ & $.223^{* *}$ \\
QWL-8 Social relevance of work life & $.646^{* *}$ & $.622^{* *}$ & $.210^{* *}$ \\
\hline Overall QWL & $.656^{* *}$ & $.559^{* *}$ & $.343^{* *}$ \\
\hline
\end{tabular}

** Correlation is significant at the 0.01 level (2-tailed).

As shown in Table 4, the first three components of QWL, i.e. QWL 1, QWL 2 and QWL3, are not significantly related to three dimensions of JP (TP, CP and CPP). There are weak, positive and significant associations among QWL 4 and three dimensions of JP i.e. $r=0.346, r=0.278$ and $r=0.246$ respectively. The other four dimensions of QWL (QWL 5, QWL 6, QWL 7 and QWL 8) have significant associations with dimensions of TP and CP (sig. at 0.01). This indicates that QWL shows strong positive relationships with TP and CP (all $r$ values are above 0.5). On the other hand, there are weak positive associations between the dimensions of QWL and CPP (all relevant correlation coefficient values are below 0.5 in table 4).

However, the overall result of the association between overall QWL and JP dimensions show (Table 4) significant relationships at the 99\% confidence level. Among them TP and CP have strong positive linear relations i.e. $r=0.656, r=0.559$, respectively, which are more than the relationship between overall QWL and CPP $(r=0.343)$. The second Hypothesis of this study stated that there is an association between the eight dimensions of QWL and the three dimensional model of JP. Accordingly, the null hypothesis of this study is rejected and the alternative hypothesis is accepted.

Hypothesis three states that there is a significant impact of QWL on JP of Station Masters who work in railways, Sri Lanka. Table 5 indicates the results of the regression analysis.

Table 5: Model Summary of Regression Result

\begin{tabular}{lrrrr}
\hline Model & $\mathrm{R}$ & R Square & Adjusted R Square & \multicolumn{2}{c}{$\begin{array}{c}\text { Std. Error of the } \\
\text { Estimate }\end{array}$} \\
\hline 1 & $.704^{\mathrm{a}}$ & .495 & .493 & 12.13519 \\
\hline
\end{tabular}

a. Predictors: (Constant), TotalQWL 
The results show that there is a strong, positive relationship between QWL and JP, having a $49.5 \% \mathrm{R}$ squared value at the $99 \%$ significance level. The findings revealed that $49.5 \%$ (almost $50 \%$ ) of JP is caused by the existing QWL practices at the railways in Sri Lanka. It also signifies that there are other factors, which contribute to JP in addition to QWL. Hence, the third hypothesis of this study is also accepted, rejecting the null hypothesis.

\section{Discussion and Conclusion}

Summary of the Findings: This study developed an integrated original conceptual model for measuring the relationship between QWL and JP among Station Masters who work in the railway sector in Sri Lanka. Three hypotheses were developed addressing three specific research problems through three specific research objectives.

Objective 1: To investigate whether there is a positive relationship between QWL and JP of Station Masters who work in Sri Lanka railways. This objective was achieved through $\mathrm{H} 1$ in Table 3. The statistical results concluded that the QWL is strongly and significantly related to the JP of Station Masters who work in Sri Lanka railways.

Objective 2: To examine the association between the eight dimensions of QWL and the three dimensional model of JP. This objective was achieved through $\mathrm{H}_{2}$ in Table 4. Accordingly, it is concluded that QWL dimensions strongly and significantly associate with the dimensions of JP of Station Masters who work in Sri Lanka railways.

Objective 3: To predict the impact of QWL on JP of Station Masters in Sri Lanka railways. This objective was achieved through $\mathrm{H}_{3}$ in Table 5 . The statistical results predicted that $49.5 \%$ (almost 50\%) of JP of Station Masters was contributed by the existing QWL practices of the railways sector in Sri Lanka.

Many researchers have done different studies related to QWL representing in different sector in different countries. None of them has presented any contradictory results in relation to QWL and JP. Each study showed a positive relationship between both variables (Beh and Rose, 2007; Gayathri, et al., 2013; Taghavi, et al., 2014; Rai, 2015; and Nair, 2015).

The findings from global context with reference to railway sector, Mazloumi, et al. (2014) concluded that the QWL has obtained a low score among the railway employees. In short, appropriate measures for improving the QWL should be adopted, especially in the area of these two factors including QWL and JP. They mentioned that safety is a more critical role among train drivers and they suggested improving the safe work environment and implementation of ergonomic programs. Hosmani, et al. (2014) studied the impact of QWL on JP amongst railway employees and they revealed that there is a high level of satisfaction among the employees regarding $\mathrm{QWL}$ as it enhances the employee JP and also organizational performance. Further findings from local context are also consistent with previous findings. Halpita, et al. (2011) also agree with previous findings and they concluded that the work environment is not appropriate for better service. Hence, they have suggested to change the existing work environment with advanced technology for better 
results of employees as well as organization. Kesavan, et al. (2015) also approve the relationship between QWL and JP adding further to the railway sector in Sri Lanka. As a result, they have highlighted the weaknesses in existing situation in Sri Lanka railways and they have proposed different solutions for further enhancement of this service in Sri Lanka.

Originality and Contribution to the Existing Literature: This study emphasized the relationship between QWL and JP which had been already established in previous foreign studies by providing Sri Lankan based empirical evidence. Working definitions developed for two variables, and dimensions and elements identified for the variables can be considered as original value additions to the existing body of knowledge. Also the conceptual model (Figure 1) is also an original model contributing theoretically as well as empirically to the existing literature.

Managerial Implications: The results revealed managerial implications related to the impact of the existing QWL practices on JP of Station Masters working in the railways sector in Sri Lanka. Findings of this study highlighted the fact that the existing QWL practices play a vital role in JP. This organization has an autocratic type of administration, which is a result of its British colonial roots. However, it needs to implement up to date work systems for the satisfaction of both internal and external customers who now live in a dynamic environment. More specially, Station Masters are not highly satisfied with the existing salary, work conditions and work environment, archaic rules and regulations and insufficient career development opportunities. Therefore, the existing human resource management practices should be modified and enriched with current, dynamic practices.

Further, the overall scores of Table 4 reveal that the overall result of the association between overall QWL and JP dimensions shows significant relationships at the 99\% confidence level. But the level of association among QWL with TP and CP shows strong positive level relationships. But the association between QWL and CPP designates a weak level relationship. Hence, the administration should follow proper strategies for managing counterproductive behavior favorably among the employees in railways.

According to the overall findings, around 50\% of QWL practices are affected to the level of JP of this category of employees in railways. Hence, except the QWL practices, other human resource management practices are needed to uplift for the future success of the railway service in Sri Lanka.

Research Limitations and Directions for Further Research: This study was limited to the railway sector in Sri Lanka, specifically to Station Masters who are only male employees. They work as multi task handlers. The study respondents were solicited at only one time (cross sectional) and the research was not conducted as a longitudinal study. Since the research was a behavioral study, a longitudinal research design could have been more appropriate. This study was based on perceptions of Station Masters which might have socially desirable error and prejudice. A qualitative study done independently would yield a true in-depth picture of QWL practices and JP of Station Masters in Sri Lanka. 


\section{References}

Al Muftah, H. and Lafi, H. (2011), Impact of QWL on employee satisfaction case of oil and gas industry in Qatar, Advances in Management and Applied Economics, Vol. 1, No. 2, pp. 107-134.

Almarshad, S. O. (2015), A Measurement Scale for Evaluating Quality of Work Life: Conceptualization and Empirical Validation, Trends in Applied Sciences Research, Vol. 10, No. 3, pp. 143-156.

Austin, J. T. and Villanova, P. (1992), The criterion problem: 1917-1992, Journal of Applied Psychology, Vol. 77, No. 6, pp. 836-874.

Baba, V.V. and Jamal, M. (1991), Reutilization of Job Context and Job Content as Related to Employee's Quality of Working Life: a study of psychiatric nurses, Journal of organizational behavior, Vol. 12, No. 1, pp. 379-386.

Beh, L. S. (2011), Challenges of quality of work life: Evidence and implications in developed and developing countries, $29^{\text {th }}$ International Labour Process Conference, University of Leeds, UK, 5-7 April.

Benardin, H.J. and Russell, J.E. (1993), Human Resource Management: An Experiential Approach, New York: McGraw Hill Inc.

Bernardin, H. J. and Beatty, R. W. (1984), Performance Appraisal: Assessing Human Behavior at Work (Kent, Boston: MA).

Boisvert, M. (1977), La Qualite de vie au travail (Ecole des Hautes Etudes Commerciales, Montreal.

Bora, B., Saumendra, D. and Murthy, V. (2015), Quality of Work Life: A Literature Review, International Journal in Management and Social Science, Vol. 3, No.3, pp. 106115.

Borman, W. C. and Brush, D. H. (1993), More Progress toward a Taxonomy of Managerial Performance Requirements, Human Performance, Vol. 6, No. 1, pp. 1-21.

Borman, W. C. and Motowidlo, S. M. (1993), Expanding the criterion domain to include elements of contextual performance, Personnel Selection in Organizations; San Francisco: Jossey-Bass, p. 71.

Brief, A. P. and Motowidlo, S. J. (1986), Prosocial Organizational Behaviors, Academy of management Review, Vol. 11, No. 4, pp. 710-725.

Bryman, A. and Bell, E. (2011), Ethics in business research, Business Research Methods, Vol.7.

Campbell, J. P., McHenry, J. J. and Wise, L. L. (1990), Modeling job performance in a population of jobs, Personnel Psychology, Vol. 43, No. 2, p. 313.

Campbell, J.P. (1990), Modeling the Performance Prediction Problem in Industrial and Organizational Psychology. In: Dunnette MD, Hough LM, eds.

Carlson, H. C. (1983), A model of quality of work life as a developmental process, Education and Training, Vol. 25, No. 1, pp. 27- 32.

Cummings, T. G. and Worley, C. G. (1997), Organization Change and Development, Mason, OH: South-Western Cengage Learning. 
Dunlop, P. D. and Lee, K. (2004), Workplace deviance, organizational citizenship behavior, and business unit performance: The bad apples do spoil the whole barrel, Journal of organizational behavior, Vol. 25, No. 1, pp. 67-80.

Ellis, R.(1994), Sri Lanka by Rail, Bradt Publications, 41 Nortoft Road, Chalfont St Peter Bucks SL9 oLA, England.

Ford, R. N. (1973), Job enrichment lessons from AT and T, Harvard Business Review, Vol. 51, No. 1, pp. 96-106.

Gayathri, and Ramakrishnan, L. ( 2013), Quality of Work Life- Linkage with Job Satisfaction and Performance. International Journal of Business and Management Invention, Vol. 2, No.1, pp. 1-8.

Gnanayudam, and Dharmasiri, A. (2007), The Influence of Quality of Work Life on Organizational Commitment, A Study of Apparel Industry, Sri Lankan Journal of Management, Vol. 12, No. 3., pp. 117-140.

Halpita, A. S., and Thelijjagoda, S. (2011), An Exploratory Study on How Technology Makes Changes in Railway Transportation in Sri Lanka, Proceedings of International Conference on Business Management, University of Kelaniya.

Havlovic, S.J. (1991), Quality of work life and human resource outcomes. Industrial Relations: A Journal of Economy and Society, Vol. 30, No. 3, pp. 469-479.

Hosmani, A., and Shambhushankar, B. (2014), Study on Impact of Quality of Work Life on Job Performance amongst Employees of Secunderabad Division of South Central Railway, Research Journal of Management Sciences, Vol. 3, No. 11, pp. 8-11.

Hosseini, S.M., Jorjafki, G.M. and Ashrafi, A.M. (2010), Notice of Retraction Quality of work life (QWL) and its relationship with performance, In Advanced Management Science (ICAMS), IEEE International Conference, pp. 559-562.

Hunt, S. T. (1996), Generic work behavior: An investigation into the dimensions of entry-level, hourly job performance, Personnel Psychology, Vol. 49, No. 1, pp. 51-83.

Kesavan, R. A., Chandrakumar, C., Kulatunga, A. K., Gowrynathan, J., Rajapaksha, R. T. D., Senewiratne, R. K. G. D. M., and Laguleshwaran, D. (2015), 150 Years of Sri Lankan Railways: Evaluation of the Services from Employee and Customer Perspectives, International Journal of Emerging Technology and Advanced Engineering, Vol. 5, No. 6.

Kiernan, W.E., and Knuston, K. (1990), Quality of work life, in R. L. Schalock and M.J. Begab (Ed.), Quality of Life: Perspectives and Issues, Washington, DC, US:xii American Association of Mental Retardation.

Koopmans, L., Bernaards, C.M., Hildebrandt, V.H., Schaufeli, W.B., De Vet, H.C.W., Vander Beek, A.J. (2011), Conceptual frameworks of individual work performance - A systematic review, Journal of Occupational and Environmental Medicine, Vol. 53, No.8, pp.856-866.

Krejcie, R.V. and Morgan, D.W. (1970), Determining sample size for research activities, Educational and psychological measurement, Vol. 30, No. 3, pp. 607-610.

Krueger, P., Brazil, K., Lohfeld, L., Edward, H. G., Lewis, D. and Tjam, E. (2002), Organization specific predictors of job satisfaction: findings from a Canadian multi-site quality of work life cross-sectional survey, BMC Health Services Research, Vol.2, No.1.

Landy, F. J. and Farr, J. L. (1983), The measurement of work performance: Methods, theory, and applications, New York: Academic Press. 
Lau, R. S. and May, B. E. (1998), A win-win paradigm for quality of work life and business performance, Human Resource Development Quarterly, Vol. 9, No. 3, pp. 211-226.

Levine, M. F., Taylor, J. C. and Davis, L. E. (1984), Defining quality of working life. Human Relations, Vol. 37, No. 1, pp. 81-104.

Mani, K. P., Sritharan, R. and Gayatri, R. (2014), Impact of Occupational Stress on Quality Work Life among Railway Station Masters of Trichy Division. Bonfring, International Journal of Industrial Engineering and Management Science, Vol. 4, No. 4, pp. 165-169.

Martel, J. P., and Dupuis, G. (2006), Quality of work life: Theoretical and methodological problems, and presentation of a new model and measuring instrument, Social indicators research, Vol. 77, No. 2, pp. 333-368.

Mazloumi, A., Kazemi, Z., Nasl-Saraji, G. and Barideh, S. (2015), Quality of working life assessment among train drivers in keshesh section of Iran Railway, International Journal of Occupational Hygiene, Vol. 6, No.2, pp. 50-55.

Mirvis, P. H. and Lawler III, E. E. (1984), Accounting for the quality of work life, Journal of Organizational Behavior, Vol. 5, No. 3, pp. 197-212.

Murphy, K. R. and Cleveland, J. N. (1995), Understanding performance appraisal: Social, organizational, and goal-based perspectives, Sage.

Murphy, K. R. (1989), Dimensions of job performance, Testing: Applied and Theoretical Perspectives, pp. 218-247, New York: Praeger.

Nadler, D. A. and Lawler, E. E. (1983), Quality of work life: perspectives and directions, Organizational dynamics, Vol. 11, No. 3, pp. 20-30.

Nair, G. S. (2013), A Study on the Effect of Quality of Work Life on Organizational Citizenship Behavior, Journal of Management, Vol. 6, No. 1, pp. 34-46.

Nayak, T. and Sahoo, C. K. (2015), Quality of Work Life and Organizational Performance: The Mediating Role of Employee Commitment, Journal of Health management, Vol. 17, No. 3, pp. 267-273.

Nunnally, J. C. (1978), Psychometric Theory, New York: McGraw-Hill.

Opatha, H.H.D.N.P. (1994), Employee grievance settlement procedure: a case study of two corporations, Management Review: Vol. 1, No.2, pp. 53-60.

Opatha, H.H.D.N.P. (2002), Performance Evaluation of Human Resources, Colombo: Institute of Management and Science.

Opatha, H.H.D.N.P. (2003), Research Methods for Human Resource Management: Questions and Answers, Colombo: Author.

Opatha, H.H.D.N.P. (2009), Human Resource Management: Personnel, Department of HRM, University of Sri Jayewardenepura, Sri Lanka.

Opatha, H.H.D.N.P. (2015), Organizational Behaviour: The Human Side of Work, Department of HRM, University of Sri Jayewardenepura, Sri Lanka.

Organ, D. W. (1988), Organizational citizenship behavior: The good soldier syndrome. Lexington Books/DC Heath and Com.

Performance Report (2017), Department of Sri Lanka Railways.

Porter, L. W. and Lawler E. E. (1974), The effect of performance on job satisfaction, Studies in Personal and Industrial Psychology, $3^{\text {rd }}$ ed, Illinois. 
Pulakos, E. D., Arad, S., Donovan, M. A. and Plamondon, K. E. (2000), Adaptability in the workplace: development of a taxonomy of adaptive performance, Journal of applied psychology, Vol. 85, No. 4, pp. 612-624.

Rai, R., and Tripathi, S. (2015), A Study on QWL and its effects on Job Performance, Journal of Management Sciences and Technology, Vol. 2, No. 2, pp. 33-42.

Ramawickrama, J., Opatha, H. H. D. N. P. and Pushpakumari, M. D. (2017a), Quality of Work Life, Job Satisfaction, and the Facets of the Relationship between the Two Constructs, Journal of International Business Research, Vol. 10, No. 4, pp. 167-182.

Ramawickrama, J., Opatha, H. H. D. N. P. and Pushpakumari, M. D. (2017b), A Synthesis towards the Construct of Job Performance, Journal of International Business Research, Vol. 10, No. 10, pp. 66-81.

Ranjan, R. and Prasad, T. (2013), Literature Review Report on Work-Life Balance of LocoPilots (Railway Drivers) in India, European Journal of Business and Management, Vol. 5, No. 19, pp. 17-27.

Rethinam, G. S. and Ismail, M. (2007), Constructs of quality of work life: A perspective of information and technology professionals, European journal of social sciences, Vol. 7 , No. 1, pp. 58-70.

Rose, R. C., Beh, L., Uli, J. and Idris, K. (2006), Quality of work life: Implications of career dimensions, Journal of Social Sciences, Vol. 2, No. 2, pp. 61-67.

Rotundo, M. and Sackett, P. R. (2002), The relative importance of task, citizenship, and counterproductive performance to global ratings of job performance: a policycapturing approach, Journal of applied psychology, Vol. 87, No. 1, pp. 66-80.

Sabarirajan, A., Geethanjali, N. and Lavanya, D. (2011), Analysis of Quality of Work Life and Perceived Public Image Among the teachers of Dindigul, Tamil Nadu, SRM Management Digest, pp. 303-308.

Saklani, D. R. (2004), Quality of work life in the Indian context: An empirical investigation. Decision, Vol. 31, No. 2, pp. 32-36.

Saraji, G. N. and Dargahi, H. (2006), Study of quality of work life (QWL), Iranian journal of public health, Vol.35, No. 4, pp. 8-14.

Satyaraju, R. and Balaram, B. (2014), Quality of Work Life of Employees, a Thesis Report submitted to Andhra university, Visakhapatnam.

Schmidt, F. L.and Hunter, J. E. (1992), Development of a causal model of processes determining job performance, Current Directions in Psychological Science, Vol. 1, No. 3, pp. 89-92.

Sekaran, U. (1992), Research Methods for Business, $2^{\text {nd }}$ ed, New York: John Wiley \& Sons, Inc.

Sekaran, U. and Bougie, R. (2013), Research Method for Business: A Skill Building Approach, New York: John Wiley \& Son, Inc.

Shekari, G., Monshizadeh, M. and Ansari, M. (2014), Investigating the relationship between quality of working life and employees' performance in Water and Wastewater Office, Khorasan Razavi.

Shouler, R.S. and Youngblood, S.A. (1986), Effective Personnel Management, $2^{\text {nd }}$ ed., West Publishing Company,

Smith, P. C. (1976), Behaviors, results, and organizational effectiveness: The problem of Criteria, Handbook of Industrial and organizational psychology, pp. 745-775. 
Stephen, A. and Dhanapal, D. (2012), Quality of Work Life in Small Scale Industrial Units: Employers and Employees Perspectives, European Journal of Social Sciences, Vol. 28, No. 2.

Steward, G. L. and Brown, K. G. (2009), HRM: Linking Strategy to Practice, John Wiley and Sons, New York.

Stokes, C. K. (2008), Adaptive performance: An examination of convergent and predictive validity (Doctoral dissertation, Wright State University).

Swamy, D.R., Nanjundeswaraswamy, T.S. and Rashmi, S. (2015), Quality of Work Life: Scale Development and Validation, International Journal of Caring Science, Vol. 8, No.2, pp. 281-300.

Tabassum, A. (2012), Interrelations between quality of work life dimensions and faculty member job satisfaction in the Private Universities of Bangladesh, European Journal of Business and Management, Vol. 4, No. 2, pp. 78-89.

Taghavi, S., Ebrahimzadh, F., BhramZadh, H. A. and Masoumeh, H. (2014), A Study of the Relationship between Quality of work life and Performance effectiveness of High School Teachers' in Shirvan. International Journal of Academic, Research in Business and Social Science, Vol. 4, No. 1, pp. 295-301.

Talebi, B., Pakdelbonab, M., Zemestani, G. and Aghdami, N. (2012), Investigation the Relationship between the Employees' Quality of Work Life (QWL) and Their Effectiveness in Banking, European Journal of Experimental Biology, Vol. 2, No.5, pp. 1839-1842.

Varghese, S. and Jayan, C. (2013), Quality of work life: A dynamic multidimensional construct at work place-part II, Guru Journal of Behavioral and Social Sciences, Vol. 1, No. 2, pp. 91-104.

Verma, A. (2015), A Study of Quality of Work Life among Employees of Diesel Locomotive Works, International Journal of Management and Social Science Research Review, Vol. 1, No. 8, pp. $19-24$.

Viswesvaran, C. and Ones, D. S. (2000), Perspectives on models of job performance, International Journal of Selection and Assessment, Vol. 8, No. 4, pp. 216226.

Viswesvaran, C. (2001), Assessment of Individual Job Performance: A Review of Past Century and a Look Ahead, Handbook of Industrial, Work and Organizational Psychology, pp. 110-126.

Walton, R.E. (1975), Criteria for Quality of Working Life. In L.E. Davis, A.B. Cherns and Associates (Eds.), The Quality of Working, New York: The Free Press, Life, Vol. 1, pp. 91104.

Wyatt, T. A. and Wah, C. Y. (2001), Perceptions of QWL: A study of Singaporean Employees Development, Research and Practice in Human Resource Management, Vol. 9, No. 2, pp. 59-76. 